\title{
Post-Reproductive Pacific Salmon, Oncorhynchus spp., as a Major Nutrient Source for Large Aggregations of Gulls, Larus spp.
}

\author{
K. S. Christie and T. E. ReImchen
}

Biology Department, University of Victoria, Victoria, British Columbia V8W 3N5 Canada; e-mail: reimchen@uvic.ca

Christie, K. S., and T. E. Reimchen. 2005. Post-reproductive Pacific salmon, Oncorhynchus spp., as a major nutrient source for large aggregations of gulls, Larus spp. Canadian Field-Naturalist 119(2): 202-207.

On the Pacific coast of North America, the most abundant vertebrate visitors to estuaries and rivers during salmon migration are gulls, yet the utilization of salmon nutrients by these scavengers, and subsequent ecological impacts are not well documented. On two forested watersheds on the central coast of British Columbia, we tracked gull abundance during the spawning period for two consecutive years, and estimated consumption of post-reproductive salmon carcasses and eggs, as well as guano production. At Clatse River, gulls (Larus glaucescens, L. argentatus, L. thayerii, L. californicus, L. canus, L. philadelphia) consumed $13-26 \%$ of total salmon carcass biomass and $29-36 \%$ of all salmon eggs deposited in the system. At Neekas River, gulls consumed $11-19 \%$ of salmon carcass biomass and 7-18\% of total salmon eggs. Local guano production over the 60-day period ranged from $600 \mathrm{~kg}$ to $1190 \mathrm{~kg}$ at Clatse and from $1200 \mathrm{~kg}$ to $2100 \mathrm{~kg}$ at Neekas River, and was distributed to marine, estuarine, freshwater and riparian habitats. The large aggregations of gulls and subsequent nutrient cycling observed on our study watersheds may represent a once widespread phenomenon that is now largely reduced due to recent declines in salmon populations.

Key Words: Gulls, Larus, nutrients, Oncorhynchus, salmon, spawning, consumption, eggs, carcasses, British Columbia.

In the north Pacific, large runs of spawning salmon (Oncorhynchus spp.) contribute substantial quantities of nutrients to aquatic and terrestrial food webs (Bilby et al. 1996; Willson et al. 1998; Willson 2004). Nutrients from salmon carcasses are used extensively by many wildlife species such as bears, marten, wolves, eagles, gulls, and ravens and become incorporated into terrestrial vegetation and invertebrate communities (Reimchen 1994*, 2000; Ben-David et al. 1998; Cederholm et al. 2000*; Helfield and Naiman 2001; Darimont and Reimchen 2002; Hocking and Reimchen 2002). The most numerous, yet least well-studied vertebrates that feed on post-reproductive salmon are gulls, which congregate in the thousands on streams throughout the north Pacific during their southward autumn migration (Mossman 1958; Campbell et al. 1990; Skagen et al. 1991). Migration and feather molt, both energetically demanding activities, require rapid accumulation of lipids (Jenni and Jenni-Eiermann 1998; Stocker and Weihs 1998; Hamer et al. 2002). These metabolic demands in addition to harsh weather conditions in the fall and winter can lead to high mortality in gulls, especially for juveniles (Burger 1993; Verbeek 1993; Hamer et al. 2002).

In this manuscript, we quantify gull abundance and foraging activity on two salmon streams of coastal British Columbia. We examine temporal shifts in abundance of gulls on each salmon stream, salmon and egg consumption by each species of gull and the recycling of salmon nutrients via guano production.

\section{Methods}

Our study was conducted on the on the central coast of British Columbia at the Clatse River $\left(52^{\circ} 20.6^{\prime} \mathrm{N}\right.$; $\left.127^{\circ} 50.3^{\prime} \mathrm{W}\right)$ and the Neekas River $\left(52^{\circ} 28.4^{\prime} \mathrm{N} ; 128^{\circ}\right.$ $\left.8.0^{\prime} \mathrm{W}\right)$, both of which support spawning populations of Chum (Oncorhynchus keta) and Pink (O. gorbuscha) salmon that spawn from late August until early November. Approximately $1 \mathrm{~km}$ from the mouth of the Clatse River and $2.1 \mathrm{~km}$ from the mouth of the Neekas River, 5-10 meter waterfalls act as barriers to further upstream migration of the salmon. These localities, both of which support more than 20000 spawning salmon, are described in detail elsewhere (Hocking and Reimchen 2002; Mathewson et al. 2003).

We made a total of 33 separate gull surveys comprising 8-9 per year at each watershed throughout the salmon spawning period. All surveys were made during low tide and included both estuary and river habitats. Gulls were counted and identified. Large gulls were grouped to facilitate identification from a distance and later identified to species in sub-sets. Among gulls that were foraging, we recorded feeding technique, and obtained classifications (surface-seizing, surface-plunging, carcass-scavenging) from Ashmole (1971). We recorded food item (carcass or eggs) consumed by sub-sets of foraging Mew Gulls. The study period extended from 9 September to 17 October in 2002 and from 25 August to 21 October in 2003.

Daily consumption of salmon carcasses and eggs was calculated for each gull species. We used the consumption model modified from Bishop and Green (2001) as follows:

\section{$\mathrm{C}=\mathrm{FMR} / \mathrm{MEC} \times \mathrm{P} \times \mathrm{M}$}

where $\mathrm{C}=$ consumption $\left(\mathrm{g} \mathrm{day}^{-1}\right)$, FMR $=$ field metabolic rate $\left(\mathrm{KJ}^{\mathrm{day}}{ }^{-1}\right), \mathrm{MEC}=$ metabolizable energy 
coefficient of salmon or eggs; $\mathrm{P}=$ proportion of salmon or eggs in diet; $\mathrm{M}=$ mass of salmon or eggs (g) needed to produce $1 \mathrm{KJ}$ energy. FMR was calculated using the allometric equation for free-living seabirds from Birt-Friesen et al (1989):

$\mathrm{FMR}=10^{(3.08+0.667 \log \mathrm{M})}$

where average body mass $(\mathrm{M}$, in $\mathrm{kg})$ was obtained from Dunning (1993) (Table 1). MEC was assumed to be 0.75 for both salmon flesh and eggs (Castro et al. 1989; Bishop and Green 2001). Energy density of senescent salmon flesh is $2.95 \mathrm{KJ} \mathrm{g}^{-1}$ (wet mass) (Hendry and Berg 1999), and for salmon eggs it is $7.60 \mathrm{KJ} \mathrm{g}^{-1}$ (wet mass) (Jonsson et al. 1998). Calculated values of FMR and consumption are shown in Table 1. Total consumption by gulls per day was derived from the mean gull count per day for each watershed. Based on the surveys at each watershed, we estimated mean daily gull abundance using two methods (1) the mean abundance of gulls derived from the original 8-9 surveys and (2) the interpolated mean, where each day was assigned a value based on temporal shifts in abundance. Although gulls occupy salmon streams throughout most of the 3-month spawning period, we estimated consumption for a 60-day period, the interval over which we had detailed data.

We calculated the proportion of total salmon biomass consumed by gulls using total consumption estimates relative to number of salmon returning to the river to spawn (escapement). Salmon escapement was obtained for our study streams in 2002 and 2003 from the Department of Fisheries and Oceans (Terry Palfrey, personal communication, Table 2). Average intact carcass mass for Pink and Chum salmon at our study sites was obtained from M. D. Hocking (personal communication, Table 2). Fecundity and egg wet mass for Pink and Chum salmon (northern mainland coast) were obtained from Beacham and Murray (1993). Pink Salmon fecundity was 1633 eggs/female and egg wet mass was $0.175 \mathrm{~g}$; Chum fecundity was 3173 eggs per female and egg wet mass was $0.278 \mathrm{~g}$. A 1:1 sex ratio was used for both Chum and Pink salmon (Heard 1991; Salo 1991). Total biomass of salmon and eggs in the system are summarized for the two watersheds in both years in Table 2 .

We calculated guano production for each species per day based on Burger et al. (1978) for Kelp Gulls: $\mathrm{G}=36.1 \mathrm{~g} \mathrm{~d}^{-1} \mathrm{~kg}^{-1}$, where $\mathrm{G}=$ output (dried) per $\mathrm{kg}$ body mass per $24 \mathrm{hrs}$. We adjusted this value to the average mass of each gull species. This estimate is congruent with that of Portnoy (1989) who found that Herring Gulls (mass $=1.1 \mathrm{~kg}$ ) produced $39.4 \mathrm{~g} \mathrm{day}^{-1}$.

\section{Results}

In both watersheds, six gull species were observed to feed on salmon carcasses and eggs: Glaucous-winged (Larus glaucescens), Herring (L. argentatus), Thayer's (L. thayeri), California (L. californicus), Mew (L. can$u s$ ), and Bonaparte's (L. philadelphia) gulls. The largebodied gulls (Glaucous-winged, Herring, Thayer's, and California gulls) mainly scavenged for salmon carcasses and occasionally consumed drifting eggs. Bonaparte's Gulls consumed eggs exclusively and most often hovered, "surface-plunging" for eggs. Bonaparte's Gulls also floated and "surface-seized" eggs from below the surface. Mew Gulls rarely surface-plunged; most of the time they were observed to either surface-seize or dislodge eggs from gravels with their feet. From behavioural observations of sub-sets of Mew Gulls,

TABLE 1. Average body mass (Dunning 1993), calculated field metabolic rate, and daily consumption of eggs or carcasses for large gulls (Glaucous-winged, Herring, Thayer's, California gulls) Mew Gulls, and Bonaparte's Gulls.

\begin{tabular}{lcccc}
\hline \hline Species & $\begin{array}{c}\text { Mean } \\
\text { body mass }(\mathrm{g})\end{array}$ & $\begin{array}{c}\text { Field metabolic } \\
\text { rate (KJ/day) }\end{array}$ & $\begin{array}{c}\text { Consumption of eggs } \\
(\mathrm{g} / \text { /bird/day) }\end{array}$ & $\begin{array}{c}\text { Consumption of carcasses } \\
(\mathrm{g} / \mathrm{bird} / \text { day })\end{array}$ \\
\hline Large gulls & 1073.0 & 1258.9 & 220.9 & 569.0 \\
Mew Gull & 403.5 & 656.2 & 115.1 & 296.6 \\
Bonaparte's Gull & 212.0 & 426.6 & 74.9 & 192.8 \\
\hline \hline
\end{tabular}

TABLE 2. Wet mass of salmon carcasses (M. D. Hocking, personal communication) and wet mass of eggs (Beacham and Murray 1993) deposited by Pink and Chum salmon at the Clatse and Neekas Rivers. Salmon escapement (Department of Fisheries and Oceans) was used to calculate total mass of carcasses and eggs deposited in each watershed in 2002 and 2003.

\begin{tabular}{llcccccccc}
\hline \hline Watershed & Species & $\begin{array}{c}\text { Mean carcass } \\
\text { wet mass } \\
(\mathrm{Kg})\end{array}$ & $\begin{array}{c}\text { Mass } \\
\text { of eggs } \\
(\mathrm{g} / \text { female })\end{array}$ & $\begin{array}{c}2002 \\
\text { escapement }\end{array}$ & $\begin{array}{c}\text { Total mass } \\
\text { of salmon } \\
(\mathrm{Kg})\end{array}$ & $\begin{array}{c}\text { Total mass } \\
\text { of eggs } \\
(\mathrm{Kg})\end{array}$ & $\begin{array}{c}2003 \\
\text { escapement }\end{array}$ & $\begin{array}{c}\text { Total mass } \\
\text { of salmon } \\
(\mathrm{Kg})\end{array}$ & $\begin{array}{c}\text { Total mass } \\
\text { of eggs } \\
(\mathrm{Kg})\end{array}$ \\
\hline Clatse & Pink & $1.1+/-0.1$ & 285.8 & 25000 & 27500 & 3573 & 25000 & 27500 & 3573 \\
& Chum & $4.2+/-0.2$ & 882.1 & 4300 & 18060 & 1897 & 6000 & 25200 & 2646 \\
& Total & & & 29300 & 45560 & 5470 & 31000 & 52700 & 6219 \\
Neekas & Pink & $1.3+/-0.1$ & 285.8 & 60000 & 78000 & 8574 & 15000 & 19500 & 2144 \\
& Chum & $3.4+/-0.2$ & 882.1 & 19000 & 64600 & 8380 & 35000 & 119000 & 15437 \\
& Total & & & 79000 & 142600 & 16954 & 50000 & 138500 & 17580 \\
\hline \hline
\end{tabular}


TABLE 3. Total consumption of salmon carcasses and eggs during the 60-day study period and proportion of the total salmon and egg biomass in the system consumed by gulls.

\begin{tabular}{|c|c|c|c|c|c|c|c|}
\hline Watershed & Year & $\begin{array}{r}\text { Tota } \\
\text { consum } \\
\text { original }^{*}\end{array}$ & $\begin{array}{l}\text { carcass } \\
\text { iption }(\mathrm{Kg}) \\
\text { interpolated } * *\end{array}$ & $\begin{array}{c}\text { Proportion of total } \\
\text { salmon biomass }\end{array}$ & $\begin{array}{r}\text { To } \\
\text { consun } \\
\text { original* }^{*}\end{array}$ & $\begin{array}{l}\text { tal egg } \\
\text { iption }(\mathrm{Kg}) \\
\text { interpolated } * *\end{array}$ & $\begin{array}{l}\text { Proportion of total } \\
\text { egg biomass }\end{array}$ \\
\hline \multirow[t]{2}{*}{ Clatse } & 2002 & 6318 & 7931 & $0.13-0.17$ & 1594 & 1987 & $0.29-0.36$ \\
\hline & 2003 & 14221 & 10419 & $0.19-0.26$ & 2150 & 1868 & $0.30-0.34$ \\
\hline \multirow[t]{2}{*}{ Neekas } & 2002 & 15785 & 19349 & $0.11-0.14$ & 1311 & 1515 & $0.07-0.09$ \\
\hline & 2003 & 26386 & 24650 & $0.18-0.19$ & 3012 & 3168 & $0.17-0.18$ \\
\hline
\end{tabular}

*derived from mean of original counts

**derived from mean of interpolated counts

approximately $93 \%$ consumed eggs and $7 \%$ consumed carcasses $(n=11, \mathrm{~s}=0.19)$. Gulls obtained eggs buried in the stream gravels, as well as those already floating downstream. They were also observed taking eggs from carcasses. Feeding intensity of large gulls was highest at low tide, when most carcasses in the estuary were exposed.

Gull abundance fluctuated over time at the two watersheds (Figure 1). At Clatse River, total daily counts of gulls reached a maximum of 1979 (13 October 2003), of which approximately $45 \%$ were large gulls. At Neekas River, maximum counts were 3594 (21 October 2003) of which $64 \%$ were large gulls. At both watersheds, Glaucous-winged and Herring gulls were the dominant species among the large gulls. Large gulls increased in abundance over the spawning period in both years at both watersheds whereas Mew and Bonaparte's gull abundance was less predictable (Figure 1). At the Clatse River, Mew and Bonaparte's gulls peaked in numbers and began to decline in early October 2002 and mid-October 2003 (Figure 1a, b) whereas at the Neekas River they did not follow a discernable pattern (Figure 1c,d). Total numbers of Mew and Bonaparte's gulls were similar between watersheds, whereas greater numbers of large gulls occurred at Neekas River.

Total consumption estimates of salmon carcasses and eggs varied between years and watersheds (Table 3 ). We estimate that $11 \%$ to $26 \%$ of total salmon carcass biomass and $7 \%$ to $36 \%$ of salmon egg biomass was consumed by gulls during the study period (Table 3). Carcass consumption was higher at the Neekas than the Clatse River, but proportions of total salmon biomass consumed were slightly less at the Neekas than the Clatse River. Although egg consumption was similar at the two watersheds, substantially higher proportions of total egg biomass were consumed at Clatse compared to Neekas River (Table 3). In general, consumption was higher in 2003 than 2002 for both watersheds.

Based on gull counts and body mass, we estimated total guano production. At Clatse River, guano output ranged from $596 \mathrm{~kg}$ to $748 \mathrm{~kg}$ in 2002 and $907 \mathrm{~kg}$ to $1192 \mathrm{~kg}$ in 2003. At Neekas River, this ranged from $1201 \mathrm{~kg}$ to $1463 \mathrm{~kg}$ in 2002 and $2006 \mathrm{~kg}$ to $2104 \mathrm{~kg}$ in 2003. Based on observed foraging and resting loca- tions of gulls, guano was distributed into multiple habitats including the river, riparian zone, estuary, and ocean.

\section{Discussion}

Gulls were significant consumers of the salmon resource and used a variety of foraging techniques and tissue types. There is an energy trade-off between the calorie-rich eggs, which require active searching, and the highly available yet low energy-density carcasses. Bonaparte's Gulls, the smallest of the gulls, are well adapted to aerial foraging and surface-seizing and commonly feed on insects and zooplankton (Baltz and Morejohn 1977; Vermeer et al. 1987; Taylor 1993). Their ability to hover above water for extended periods of time may facilitate their ability to effectively spot and capture eggs in the river. The larger gulls, in contrast, with a greater body mass and wing-loading, may incur additional energy costs of continuous-flapping flight which may outweigh the benefits of obtaining the more energy-rich food. These gulls were observed on occasion to surface-plunge for eggs, indicating that at certain times, benefits of capturing eggs outweighed energy costs. Although other food sources such as benthic invertebrates were available in the estuaries, we only observed gulls foraging on salmon tissues and eggs. Gulls tend to maximize their utilization of temporary resources, focusing on localized concentrations of prey (Shealer 2002), and it is probable that when eggs and carcasses are easily available on salmon streams, gulls feed solely on this resource.

Abundance of gulls at the Clatse and Neekas Rivers fluctuated over the study period and appeared to correspond with food availability. Large gull abundance increased over time on each watershed in both years, corresponding with the accumulation of spawned-out salmon on the stream banks and in the estuary. Abundance of Bonaparte's Gulls and Mew Gulls, however, was not correlated with carcass accumulation. We suspect that the rate of egg loss, which is associated with spawning density and flooding events, may be an important predictor of Mew and Bonaparte's Gull abundance. The two watersheds had similar numbers of Mew and Bonaparte's Gulls despite the higher biomass of salmon at the Neekas River, indicating that comparable quantities of eggs were being lost from 

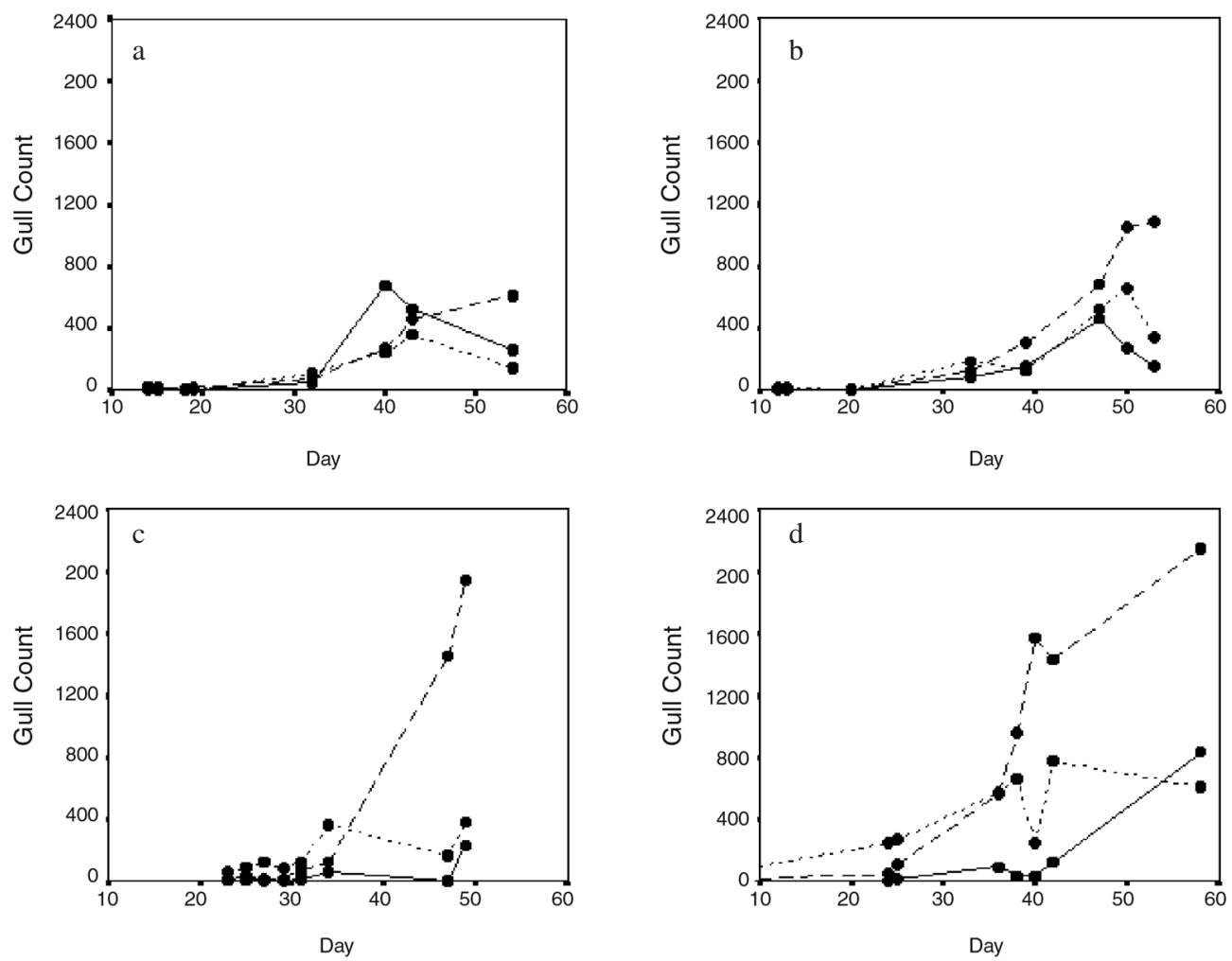

FIGURE 1a-d. Change in abundance of gulls over time (day $1=25$ August; day $60=23$ October) for Clatse River: (a) 2002 and (b) 2003 and Neekas River (c) 2002 and (d) 2003. Dashed lines represent large gulls (Glaucous-winged Gulls, Herring Gulls, Thayer's Gulls, California Gulls), dotted lines represent Mew Gulls, and solid lines represent Bonaparte's Gulls.

the two watersheds even though the Clatse River had fewer spawning salmon. High stream velocity can result in egg loss, causing eggs to be washed out of redds after being deposited (Vronskii and Leman 1991). This effect may be accentuated at Clatse River where recent logging in the headwaters will have lead to higher stream velocities and reduced gravel stability. Egg loss from salmon redds can also be linked with high salmon spawning density, which results in redd superimposition and subsequent egg dislodgement (Fukushima et al. 1997). It is possible that fluctuations in gull abundance were related to timing of migration rather than prey abundance. Mace (1983) observed aggregations of Bonaparte's Gulls feeding on juvenile salmonids in the spring and found abundance of gulls to be directly related to migration.

Gulls were major consumers of both salmon carcasses and eggs. Our estimates for consumption of carcasses at the Neekas and Clatse rivers are conservative because our 60-day study period ended before gulls had departed from the stream. Extrapolating abundance throughout the duration of the spawning period might increase consumption by as much as $30 \%$. Our results are comparable to those of other studies of gulls feeding on fish or eggs (Gabrielsen et al. 1987; Haegele
1993; Bishop and Green 2001). High numbers of eggeating gulls at the Clatse River led to a substantial proportion (29-36\%) of eggs deposited in the system being consumed. Only a small proportion of eggs would have been dislodged from buried redds; most eggs were already floating downstream before capture by gulls. It is not unusual for large quantities of eggs to be lost from salmon redds; for example, average egg loss rates of $48.6 \%$ and $56 \%$ have been reported for Pink Salmon (Eniutina 1972; Heard 1991). In general, higher proportions of salmon and eggs were consumed in 2003 than 2002, largely because there was less total salmon available in 2003. Between-year differences at the Neekas River must be interpreted cautiously, however, because of the short study period in 2002 .

Gulls contributed to the cycling of nutrients from salmon into terrestrial and aquatic ecosystems through guano and feather deposition. Seabird guano has been reported to enrich plants in nitrogen and phosphorus (Anderson and Polis 1999; Garcia et al. 2002), increase abundance of terrestrial arthropods (SanchezPinero and Polis 2000), and increase primary productivity in the intertidal zone (Bosman and Hockey 1986). Guano from gulls and other avian scavengers on salmon streams likely contributes to the nitrogen and 
phosphorous content of otherwise nutrient-deprived coastal forests and streams (Waring and Franklin 1979; Kiffney and Richardson 2001). In addition, gulls undergo an annual molt after breeding (Taylor 1993; Vandenbulcke 1989), and their feathers, containing high concentrations of mineral elements and energy (Williams and Berruti 1978) are shed into the riparian zone, stream, and estuary.

Salmon streams may provide an important food resource for gulls, particularly the smaller species such as Mew and Bonaparte's gulls. Salmon streams offer a highly predictable, nutritional and accessible food source to gulls dispersing from breeding grounds in search of abundant food resources at a time of high energy expenditure (feather molt, migration) and high juvenile mortality (Burger 1993; Hamer et al. 2002). There are roughly 2500 spawning streams in British Columbia, many of which attract aggregations of gulls during the autumn and winter. Assemblages of gulls have been reported to utilize salmon streams in Washington (Skagen et al. 1991), Vancouver Island (personal observation), the Queen Charlotte Islands (Reimchen 1992*) and Alaska (Mossman 1958). The large numbers of gulls observed on the Clatse and Neekas Rivers, which have relatively intact salmon runs, are representative of an ecological phenomenon that has been greatly diluted throughout the Pacific Northwest. Gresh and Lichatowich (2000) estimated a 93-95\% reduction in salmon biomass on the west coast of North America over the last century which results reduced availability of this food source for gulls and for numerous other vertebrates species that utilize salmon nutrients (Cederholm et al. 2000*). The importance of gull assemblages to the ecology of coastal terrestrial ecosystems is unknown, but gulls have the potential to be important nutrient vectors and thus may contribute to the primary productivity of nutrient-deprived terrestrial systems.

\section{Acknowledgments}

We thank Alan Burger for his helpful comments on the manuscript, Karen Petkau, Morgan Hocking, Janine Arnold, Bob Wilkerson, Sara Steinke and Jocelyn Akins for assistance in the field, Chris Darimont, Raincoast Conservation Society and Larry Jorgenson for providing accomodation in the field, Terry Palfrey at the Department of Fisheries and Oceans for fish escapement data, The Natural Sciences and Engineering Research Council of Canada (NSERC), The Friends of Ecological Reserves, The David Suzuki Foundation, Mountain Equipment Co-op Environment Fund, Bird Studies Canada, and Science Horizons Youth Internship Program for financial support, and The Heiltsuk Nation for allowing this study to take place in their territory.

Documents Cited (marked $*$ in text)

Cederholm, C. J., D. H. Johnson, R. E. Bilby, L. G. Dominguez, A. M. Garrett, W. H. Graeber, E. L Greda, M.
D. Gunze, B. G. Marcot, J. F. Palmisano, R. W. Plotnikoff, W. G. Pearcy, C. A. Simenstad, and P. C. Trotter. 2000. Pacific Salmon and wildlife - ecological contexts, relationships, and implications for management. Special Edition Technical Report, Prepared for D. H. Johnson and T. A. O'Neil (Managing Directors), Wildlife-Habitat Relationships in Oregon and Washington. Washington Department of Fish and Wildlife, Olympia, Washington. 136 pages.

Reimchen, T. E. 1992. Mammal and bird utilization of adult salmon in stream and estuarine habitats at Bag Harbour, Moresby Island. Canadian Wildlife Service Report. Queen Charlotte City, British Columbia.

Reimchen, T. E. 1994. Further studies of predator and scavenger use of chum salmon in stream and estuarine habitats at Bag Harbour, Gwaii Haanas. Canadian Parks Service Report. Queen Charlotte City, British Columbia.

\section{Literature Cited}

Anderson, W. B., and G. A. Polis. 1999. Nutrient Fluxes from water to land: seabirds affect plant nutrient status on Gulf of California islands. Oecologia 118: 325-332.

Ashmole, N. P. 1971. Sea Bird ecology and the marine environment. Pages 224-271 in Avian Biology, Volume 1. Edited by D. S. Farner and J. R. King. Academic Press, New York, New York.

Baltz, D. M, and G. V. Morejohn. 1977. Food habits and niche overlap of seabirds wintering on Monterey Bay, California. Auk 94: 527-542.

Beacham, T., and C. B. Murray. 1993. Fecundity and egg size variation in North American Pacific salmon (Onchorhynchus). Journal of Fisheries Biology 42: 485-508.

Ben-David, M., T. A. Hanley, and D. M. Schell. 1998. Fertilization of terrestrial vegetation by spawning pacific salmon: the role of flooding and predator activity. Oikos 83: 47-55.

Bilby, R. E., B. R. Fransen, and P. A. Bisson. 1996. Incorporation of nitrogen and carbon from spawning coho salmon into the trophic system of small streams: evidence from stable isotopes. Canadian Journal of Fisheries and Aquatic Sciences 53: 164-173.

Birt-Friesen, V. L., W. A. Montevecchi, D. K. Cairns, and S. A. Macko. 1989. Activity-specific metabolic rates of free-living northern gannets and other seabirds. Ecology 70: 357-367.

Bishop, M. A., and S. P. Green. 2001. Predation on Pacific Herring (Clupea pallasi) spawn by birds in Prince William Sound, Alaska. Fisheries Oceanography 10: 149-158.

Bosman, A. L., and P. A. R. Hockey. 1986. Seabird guano as a determinant of rocky intertidal community structure. Marine Ecology Progress Series 32: 247-257.

Burger, A. E. 1993. Mortality of seabirds assessed from beached-bird surveys in southern British Columbia. Canadian Field-Naturalist 107: 164-176.

Burger, A. E., H. J. Lindeboom, and A. J. Williams. 1978. The mineral and energy contributions of guano of selected species of birds to the Marion Island terrestrial ecosystem. South African Journal of Antarctic Research 8: 59-70.

Campbell, W., N. K. Dawe, I. McTaggart-Cowan, J. M. Cooper, G. W. Kaiser, and M. C. E. McNall. 1990. The Birds of British Columbia. Volume 2. Royal British Columbia Museum, Victoria, British Columbia.

Castro, G., N. Stoyan, and J. P. Myers. 1989. Assimilation efficiency in birds: a function of taxon or food type? Comparative Biochemical Physiology 92: 271-278. 
Darimont, C. T., and T. E. Reimchen. 2002. Intra-hair stable isotope analysis suggests seasonal shift to salmon in gray wolf diet. Canadian Journal of Zoology 80: 1638-1642.

Dunning, J. B. 1993. CRC handbook of avian body masses. CRC Press Inc. Boca Raton, Florida.

Eniutina, R. I. 1972. The Amur pink salmon (Oncorhynchus gorbuscha): a commercial and biological survey. Fisheries Research Board of Canada Translation Series Number 3160 .

Fukushima, M., T. J. Quinn, and W. W. Smoker. 1997. Estimation of eggs lost from superimposed Pink salmon (Oncorhynchus gorbuscha) redds. Canadian Journal of Fisheries and Aquatic Sciences 55: 618-625.

Gabrielsen, G. W., F. Mehlum, and K. A. Nagy. 1987. Daily energy expenditure and energy utilization of free-ranging Black-legged Kittiwakes. The Condor 89:126-132.

Garcia, L. V., T. Maranon, F. Ojeda, L. Clemente, and R. Redondo. 2002. Seagull influence on soil properties, chenopod shrub distribution, and leaf nutrient status in semiarid Mediterranean islands. Oikos 98: 75-86.

Gresh, T., and J. Lichatowich. 2000. An estimation of historic and current levels of salmon production in the northeast pacific ecosystem: evidence of a nutrient deficit in the freshwater systems of the Pacific Northwest. Fisheries 25: 15-21.

Haegele, C. W. 1993. Seabird predation of Pacific Herring, Clupea pallasi, spawn in British Columbia. Canadian FieldNaturalist 107: 73-82.

Hamer, K. C., E. A. Schreiber, and J. Burger. 2002. Breeding biology, life histories, and life history-environment interactions in seabirds. Pages 217-261 in Biology of Marine Birds. Edited by E. A. Schreiber, and J. Burger. CRC Press, Florida.

Heard, W. R. 1991. Life history of Pink Salmon (Oncorhychus gorbuscha). Pages 119-230 in Pacific salmon life histories. Edited by C. Groot and L. Margolis. UBC Press, Vancouver, British Columbia.

Helfield, J. M., and R. J. Naiman. 2001. Effects of salmonderived nitrogen on riparian forest growth and implications for stream productivity. Ecology 82: 2403-2409.

Hendry, A. P., and O. K. Berg. 1999. Secondary sexual characters, energy use, senescence, and the cost of reproduction in sockeye salmon. Canadian Journal of Zoology 77: 1663-1675.

Hocking, M. D., and T. E. Reimchen. 2002. Salmon-derived nitrogen in terrestrial invertebrates from coniferous forests of the Pacific Northwest. BMC Ecology 2: 1-14.

Jenni, L., and S. Jenni-Eirmann. 1998. Fuel supply and metabolic constraints of migrating birds. Journal of Avian Biology 29: 521-528.

Jonsson, N., B. Jonsson, and L. P. Hansen. 1998. The relative role of density-dependent and density independent survival in the life cycle of atlantic salmon Salmo salar. Journal of Animal Ecology 67: 751-762.

Kiffney, P. M., and J. S. Richardson. 2001. Interactions among nutrients, periphyton, and invertebrate and vertebrate (Ascaphus truei) grazers in experimental channels. Copeia 2: 422-429.

Mace, P. M. 1983. Bird predation on juvenile salmonids in the Big Qualicum Estuary, Vancouver Island. Canadian Technical Report of Fisheries and Aquatic Sciences Number 1176 .

Mathewson, D. D., M. D. Hocking, and T. E. Reimchen. 2003. Nitrogen uptake in riparian plant communities across a sharp ecological boundary of salmon density. BMC Ecology 3: 4.

Mossman, A. S. 1958. Selective predation of Glaucouswinged Gulls upon adult red salmon. Ecology 39: 482-486.

Portnoy, J. W. 1989. Gull contributions of phosphorous and nitrogen to a Cape Cod kettle pond. Hydrobiologia 202: 61-70.

Reimchen, T. E. 2000. Some ecological and evolutionary aspects of bear - salmon interactions in coastal British Columbia. Canadian Journal of Zoology 78: 448-457.

Salo, E. O. 1991. Life history of chum salmon (Oncorhychus keta). Pages 231-310 in Pacific Salmon Life Histories. Edited by C. Groot and L. Margolis. UBC Press, Vancouver, British Columbia.

Sanchez-Pinero, F., and G. A. Polis. 2000. Bottom-up dynamics of allochthonous input: direct and indirect effects of seabirds on islands. Ecology 81: 3117-3131.

Shealer, D. A. 2002. Foraging behavior and food of seabirds. Pages 137-177 in Biology of Marine Birds. Edited by E. A. Schreiber and J. Burger. CRC Press, Florida.

Skagen, S. K., R. L. Knight, and G. H. Orians. 1991. Human disturbance of an avian scavenging guild. Ecological Applications 1: 215-225.

Stocker, S., and D. Weihs. 1998. Bird migration - an energybased analysis of costs and benefits. Journal of Mathematics Applied in Medicine and Biology 15: 65-85.

Taylor, P. 1993. Migration of Bonaparte's Gull, Larus philadelphia, in Southeastern Manitoba. Canadian Field-Naturalist 107: 314-318.

Vandenbulcke, P. 1989. Larus argentatus ssp. and Larus cachinnans-michahellis along the Belgian coast: origin and moulting. Le Gerfaut 79: 3-30.

Verbeek, N. A. M. 1993. Glaucous-winged Gull (Larus glaucescens) in The birds of North America (59). Edited by A. Poole, P. Stettenheim, and F. Gill. The Academy of Natural Sciences, Philadelphia, Pennsylvania, and the American Ornithologists' Union, Washington, D.C.

Vermeer, K., I. Szabo, and P. Greisman. 1987. The relationship between plankton-feeding Bonaparte's and Mew Gulls and tidal upwelling at Active Pass, British Columbia. Journal of. Plankton Research 9: 483-501.

Vronskii, B. B., and V. N. Leman. 1991. Spawning beds, hydrological regime, and progeny survival in the redds of the chinook salmon, Oncorhynchus tshawytscha in the Kamchatka River Basin, Russian SFSR USSR. Journal of Ichthyology 31: 282-291.

Waring, R. H., and J. F. Franklin. 1979. Evergreen coniferous forests of the Pacific Northwest. Science 204: 13801386.

Williams, A. J., and A. Berruti. 1978. Mineral and energy contributions of feathers moulted by penguins, gulls and cormorants to the Marion Island terrestrial ecosystem. South African Journal of Antarctic Research 8: 71-74.

Willson, M. F. 2004. Gulls, Larus spp. foraging at Pink Salmon, Oncorhynchus gobusch, spawning runs. Canadian Field-Naturalist 114(3): 442-443.

Willson, M. F., S. M. Gende, and B. H. Marston. 1998. Fishes and the Forest: Expanding perspectives on fish wildlife interactions. BioScience 48: 455-462.

Received 12 March 2004

Accepted 8 March 2005 